\title{
Adhesiolysis-Related Challenges for Laparoscopic Procedures after Ventral Hernia Repair with Intraperitoneal Mesh
}

\author{
Florin Turcu, Octavian Arnautu, Catalin Copaescu
}

Ponderas AH Hospital, Bucharest, Romania

Corresponding author:

Catalin Copaescu, MD PhD

Associated Professor of Surgery

Ponderas Academic Hospital

Nicolae Caramfil Street, no. 85 A

district 1, Bucharest, Romania

E-mail: catalin.copaescu@ponderas-ah.ro

\section{Abbreviations:}

POA - postoperative adhesions; IPOM - Intraperitoneal Onlay Mesh; IRB - Institutional review board; CT - Computer-Tomography.

\section{Rezumat}

Dificultăți legate de adezioliză pentru procedeele laparoscopice efectuate după aloplastia intraperitoneală a herniilor ventrale

Background: Procedurile laparoscopice la pacienții cu antecedente chirurgicale abdominale pot fi dificile datorită riscului necunoscut al aderentelor postoperatorii (POA). Technica de aloplastie intraperitoneală (IPOM) este frecvent utilizată pentru hernioplastia ventrală laparoscopică sau deschisă. Riscul de POA poate fi crescut la aceşti pacienți, astfel încât orice explorare laparoscopică ulterioară ar putea fi considerată dificilă.

Scopul studiului nostru este de a analiza provocările şi complicațiile legate de adezioliză la pacienții care necesită intervenție chirurgicală laparoscopică după aloplastia intraperitoneală a herniei ventrale (IPOM).

Metoda: Toți pacienții la care s-au efectuat proceduri laparoscopice după aloplastia intraperitoneală a herniei ventrale (IPOM) în Ponderas Academic Hospital din mai 2011 până în decembrie 2018 au fost incluşi într-un studiu retrospectiv. Doi experți instruiți au analizat toate înregistrările video şi au colectat date privind istoricul chirurgical, localizarea şi densitatea aderențelor, dificultatea de disecție, intervalul de timp pentru adezioliza la plasă şi complicatiile asociate.

Rezultate: 29 de pacienți au fost incluşi în studiu. Au fost 17 femei, cu vârsta medie de 58,0 $\pm 14,5$ ani, IMC mediu de $28,7 \pm 7,0 \mathrm{~kg} / \mathrm{m}^{2}$ şi un număr median de intervenții chirurgicale abdominale de 3/pacient. Factorii de risc pentru formarea aderențelor, alții decât cei asociați protezelor textile au fost găsiți la 16 pacienți. Mediana duratei timpului scurs de la ultima procedură IPOM la explorarea laparoscopică a fost de 26 luni. Indicația a fost impusă de tehnica de reparare a herniei la 21 de pacienți şi pentru alte patologii la 8 
pacienți. Aderențele la plasă au fost găsite în majoritatea cazurilor (96\%). Scorul mediu al aderențelor la suprafață şi tenacitatea la aderență a fost de 4,0 $\pm 1,7$ şi respectiv $3,0 \pm 0,8$. Timpul median de realizare a adiozolizei la plasă a fost de 22 minute. În timpul disecției, intestinul subțire a fost deschis la şase pacienți. Migrarea materialului textil în intestin a fost întâlnită în două cazuri. Au fost trei conversii la tehnica deschisă şi una la chirurgie robotică. Istoricul de peritonită şi complicațiile septice la ultima interventie chirurgicală au fost asociate în mod semnificativ cu o rată mai mare de conversie. $\mathrm{Au}$ fost consemnate infecție de plagă şi nici o infecție a protezei. Durate mediană de spitalizare a fost de 4 zile. Mortalitatea postoperatorie la 30 de zile a fost zero. Urmărirea postoperatorie mediană a fost de 13 luni. Au fost consemnate 3 hernii incizionale.

Concluzii: Studiul demonstrează că abordarea laparoscopică după IPOM este fezabilă, dar provocatoare. Aderențele la proteza textilă sunt aşteptate în majoritatea cazurilor. Istoricul de peritonită, un număr mare de proceduri abdominale deschise şi complicațiile septice la ultima intervenție chirurgicală se corelează cu o mare dificultate de adezioliză.

Cuvinte cheie: aloplastie intra-peritoneală (IPOM), aderențe, plasă, laparoscopie

\begin{abstract}
Background: Laparoscopic procedures in patients with history of abdominal surgery can be challenging due to the unknown risk of postoperative adhesions (POA). The intraperitoneal onlay mesh procedures (IPOM) are frequently used for open or laparoscopic repair for incisional and ventral hernia. The risk of PoA can be increased in these patients, thus, any further laparoscopic exploration might be considered difficult.

The aim of our study is to analyze the adhesiolysis-related challenges and complications in patients requiring laparoscopic surgery after IPOM ventral hernia repair.

Methods: All the patients who underwent any laparoscopic procedure after open or video-assisted IPOM ventral hernia repair in Ponderas Academic Hospital from May 2011 to December 2018, were retrospectively analyzed. Two trained experts reviewed all video recordings and collected data on surgical history, adhesion location and density, dissection difficulty, interval time to release adhesions from the mesh and complications.

Results: Twenty-nine patients were included into the study. There were 17 females, mean age of $58.0 \pm 14.5$ years, mean BMI of $28.7 \pm 7.0 \mathrm{Kg} / \mathrm{m}^{2}$ and a median number of abdominal surgeries of $3 /$ patient. Risk factors for adhesion formation, other than the mesh itself were found in 16 patients. The median time from the last IPOM procedure to the laparoscopic exploration was 26 months and it was related to the hernia repair technique in 21 patients and indicated for other pathologies in 8 patients.Adherences to the mesh were found in the majority of the cases (96\%). The mean score of surface adhesion and adhesion tenacity was $4.0 \pm 1.7$ and $3.0 \pm 0.8$, respectively. The median time to complete the adhesiolysis to the mesh was 22 minutes. Small bowel was open during the dissection in six patients. Mesh migration was encountered in two. There were three conversions to open surgery and one to robotic surgery. History of peritonitis and septic complications at the last surgery were significantly associated with a higher rate of conversion. One surgical site infection and no mesh infection were encountered. The median postoperative hospital stay was 4 days. The 30-day postoperative mortality was nil. The median postoperative follow-up was 13 months. There are 3 recurrent incisional hernias.

Conclusions: The study demonstrates that laparoscopic approach after previous IPOM is feasible but challenging. Adherences to the mesh are expected in the majority of the cases. History of peritonitis, a large number of open abdominal procedures, and septic complication at last surgery correlate with a high difficulty of adhesiolysis.
\end{abstract}

Key words: IPOM ventral hernia repair, adhesions, mesh, laparoscopy 


\section{Introduction}

Planning and performing any laparoscopic procedure in patients with history of abdominal surgery can be challenging due to the unknown risk of postoperative adhesions (POA) (1-3).

The POA formation is highly influenced by different risk factors associated with the surgical procedure and the patients' characteristics (3-7).

Out of the various surgical options for ventral hernia repair, the one placing the prosthesis on the inner lining of the abdomen - the Intraperitoneal Onlay Mesh (IPOM) - is technically less demanding but it can be associated with an increased risk of POA formation (8). The laparoscopic technique for ventral and incisional hernia repair was introduced and mostly developed as an IPOM procedure (9). Moreover, despite the quality improvements in composite meshes proposed to be used in the intraperitoneal space, the ideal one has yet to be found.

Considering the growing popularity of the laparoscopic or open IPOM ventral hernia repair and the fact that a certain number of these patients might need surgical exploration, the study of this cohort's characteristics is very important. The minimal-invasive approach should be preferred in these very patients as open surgery can affect the already introduced abdominal wall prosthesis.

The indication for the laparoscopic approach in patients having an intraperitoneal mesh can be related to the POA or mesh morbidity (10, 11), hernia recurrence, or for the surgical treatment of any other abdominal pathology. However, the endoscopic approach is expected to be very difficult due the POA presence.

The aim of our study is to analyze the adhesiolysis-related challenges and complications in patients requiring laparoscopic surgery after IPOM ventral hernia repair.

\section{Methods}

The present study has retrospectively analyzed all the patients who underwent any laparoscopic procedure after open or videoassisted ventral hernia repair with intra- peritoneal mesh (IPOM), between May 2011 to December 2018. The patients were selected from the prospectively maintained data base of endoscopic surgery procedures performed in our institution (Ponderas Academic Hospital). The study has been approved by the Institutional review board (IRB).

Preoperative patient data including gender, age, BMI and co morbidities were collected.

History of abdominal surgery and the associated events were analyzed including: number of previous abdominal laparoscopic and open surgical procedures, the history of peritonitis, number of previous ventral/incisional hernia repairs, the timing of the IPOM procedure, the type of prosthesis used for IPOM and the last surgical procedure.

In this study, laparoscopic surgery was indicated for complications associated with ventral hernia repair (including recurrence) or for any other abdominal pathology, not related to the abdominal wall repair.

The preoperative work-up has included the Computer-Tomography (CT) scan evaluation in all the patients. This is a routine examination protocol applied in our Center of Excellence in Hernia Surgery (SRC) to all the patients who undergo to /have history of ventral hernia surgery with or without mesh. The patients for whom the mesh was placed sublay, in-lay or subcutaneous/supraaponeurotic onlay mesh were excluded from the present study.

All procedures were recorded respecting the regulations of personal data protection and the requirements of the IRB. All the patients signed the informed consent.

\section{Analyze of the laparoscopic surgery challenges}

Access to the peritoneal cavity was blind, using Veress needle insufflation and the introduction of an optical trocar on the lateral abdominal wall, away from the site or sites of previous surgery. The Hasson technique was used only in selected cases.

All the video recordings of the procedures were evaluated by two separate trained researchers who collected data on adhesions' location, adhesions' tenacity, time to complete 
the adhesiolysis within the mesh's borders (minutes), inadvertent organ damage such as enterotomies, the operative time for access to the peritoneum and total operation time.

Un-existing, damaged, incomplete or poor quality of videos were considered excluding criteria.

The adhesiolysis was performed by sharp dissection with scissors or by blunt dissection, with minimal use of electrocautery. Adhesion tenacity was graded (0-4) based on Jenkins scale (12) (Table 1).

The surface area of adhesions covering the mesh was estimated in increments of $20 \%$ (Table 2).

The intraoperative and the postoperative complications and the procedure's outcomes were analyzed. The follow up was measured from surgery to the last presentation in our hospital.

\section{Statistical Analysis}

Descriptive statistics were used to summarize patient demographics and for a preliminary analysis of data (normality, counts, etc). The data analysis program used was $\mathrm{R}$ software for Windows. For the continuous data with non-normal distributions, median and range was reported instead of mean \pm sd. For categorical data, the comparisons were made using Fisher's Exact Test (because the small number of cell counts) and Mann-Whitney test for continuous data with non-normal distributions. The threshold for statistical significance was set at 0.05 (CI 95\%).

\section{Results}

Twenty-nine patients who underwent laparoscopic procedures after open or video-assisted ventral hernia repair with intraperitoneal mesh (IPOM) between May 2011 to December 2018, were identified to match the including criteria and were included into the study. No case was excluded from the study.

The study included 17 females, with an average age of $58.0 \pm 14.5$ years (range 14-81 years) and the preoperative body mass index
Table 1. Adhesion tenacity

\begin{tabular}{lr}
\hline Adhesion characteristics & Score \\
\hline No adhesion & 0 \\
\hline Filmy adhesion: viscera/omentum not attached & \\
to mesh disrupted manually & \\
\hline Dense adhesion: viscera/omentum attached & \\
to mesh requiring blunt dissection to separate \\
viscera/omentum from mesh \\
Dense adhesion: viscera/omentum attached \\
to mesh requiring sharp dissection to separate \\
viscera/omentum from mesh \\
$\begin{array}{l}\text { Dense adhesion: viscera/omentum entwined } \\
\text { in the mesh requiring sharp dissection to separate } \\
\text { mesh from abdominal wall leaving mesh attached } \\
\text { to viscera/omentum }\end{array}$ \\
\hline
\end{tabular}

Table 2. Adhesion surface area

\begin{tabular}{lc}
\hline Adhesion percentage & Score \\
\hline No adhesion & 0 \\
\hline $0-20 \%$ & 1 \\
\hline $21-40 \%$ & 2 \\
\hline $41-60 \%$ & 3 \\
\hline $61-80 \%$ & 4 \\
\hline $81-100 \%$ & 5 \\
\hline
\end{tabular}

(BMI) of $28.7 \pm 7.0 \mathrm{Kg} / \mathrm{m}^{2}$ (range 15.2 - 43). Five patients were smokers. The median number of abdominal surgeries per patient was 3 (range 114) from which open with a median of 2 (range 0-13) and laparoscopic with a median of 1 (range 0 - 4).

The risk factors for adhesion formation, other than the mesh itself were analyzed for this cohort and they were identified in 16 patients. History of peritonitis was found in nine patients, an open approach for the last surgery in 7 patients, the digestive tract was opened during the last surgery in 5 patients and septic complications during the last surgery were recorded in 8 patients. In this subgroup (16 patients) the number of risk factors per patient was between 1 and 4 (with a median value of 2 ).

The type of mesh and the fixation type used during IPOM procedure are presented in Table 3. One patient has two types of prosthesis, and in another one a biologic mesh has replaced an infected polypropylene mesh. 
Table 3. Type of mesh and fixation used for the IPOM repair

\begin{tabular}{lc}
\hline Mesh & No of patients \\
\hline Uncoated polypropylene mesh & 2 \\
\hline Permanent-barrier composite mesh & 5 \\
\hline Absorbable-barrier-coated mesh & 22 \\
\hline Biologic mesh & 1 \\
\hline Fixation & \\
\hline Titanium tackers & 19 \\
\hline Absorbable tackers & 6 \\
\hline Polypropylene monofilament suture & 4 \\
\hline
\end{tabular}

The meshes were grouped in four categories, depending on the material and barrier type: uncoated polypropylene mesh, permanentbarrier composite mesh (e.g. Bard-Composix, Davol, Inc., Cranston, RI), absorbable-barriercoated mesh (e.g. Sepramesh, Davol, Inc., Warwick, RI;), and biologic mesh (e.g. Permacol TM, Covidien, Mansfield, MA).

The median time from the IPOM procedure to the laparoscopic exploration was 26 months (range 20 days -46 months).

The indication for laparoscopic surgery was related to the IPOM ventral hernia repair technique in 21 patients and indicated for other pathologies in 8 patients: morbid obesity (4 patients), gastro esophageal reflux disease (1 patient), colonic cancer (1 patient), gynecological pathology (1 patient) and nephrectomy (1 patient).

All the respective videos of the laparoscopic procedures were reviewed.

The pneumoperitoneum was created by means of aVeress needle in 25 cases. The open Hasson approach was used in four patients.
The median time from the first attempt to introduce the optic trocar to the insertion of the first working trocar was 2 minutes (range 1-10 minutes). There was no inadvertent opening of the digestive lumen at the insertion of the trocars.

Adherences to the mesh have been evaluated in all the 29 patients. In 7 patients out of 19 cases in which metallic fixation was used, there were no adherences to the tackers. The mean score of surface adhesion was $4.0 \pm 1.7$ (median 5). The omentum was adherent to the mesh in 27 cases, the small bowel in 10 cases and the colon in 2 cases.

The mean score of adhesion tenacity was 3.0 \pm 0.8 . Sharp dissection was needed in 21 cases and dissection between the mesh and the abdominal wall was needed in 4 cases due to very intense adhesions or enteral migration. Three out of these very difficult cases were converted to open surgery and the reasons to change the approach were: difficult dissection with inadvertent opening of the small bowel, mesh penetrating/migrating into the small bowel and very difficult adhesiolysis - for the case with biological mesh previously implanted. The fourth case was converted to robotic surgery for difficult adhesiolysis and mesh migration into the bowelin a patient with ileal neo-bladder and IPOM ventral hernia repair.

Two risks factors have a significant association with the conversion from laparoscopic surgery:the septic complication at the last surgery $(p=0.042)$ and the number of former laparotomy $(\mathrm{p}=0.036)$ Table 4.

Table 4. Risk factors for conversion

\begin{tabular}{|c|c|c|c|}
\hline & $\begin{array}{c}\text { Conversion } \\
(n=4)\end{array}$ & $\begin{array}{l}\text { No Conversion } \\
(n=25)\end{array}$ & $\mathrm{p}$ value \\
\hline History of peritonitis & 3 & 6 & $0.076^{*}$ \\
\hline Open approach at last surgery & 2 & 5 & $0.238^{*}$ \\
\hline Digestive tract open at last surgery & 2 & 3 & $0.127 *$ \\
\hline Septic complication at last surgery & 3 & 5 & $0.042^{*}$ \\
\hline No. Abdominal surgery & $4.5(3-11)$ & $3(1-14)$ & $0.097^{* *}$ \\
\hline No. Laparotomy & $4.5(2-9)$ & $1(0-13)$ & $0.036^{* *}$ \\
\hline
\end{tabular}


The inadvertent opening of the digestive tract has a significant association with: an open approach at last surgery $(\mathrm{p}=0.018)$ and the number of former laparotomies $(\mathrm{p}=0.005)$ Table 5 .

The median time to complete the adhesiolysis to the mesh was 22 minutes (range 0-100).

Small bowel was open during the dissection in six patients. In two cases the mesh was already migrated into the small bowel while in one case the incident was not related to the adhesiolysis to the mesh. All injuries were immediately recognized. These incidents were resolved as follows: enterectomy after conversion to open surgery in 2 patients, laparoscopic suturing (1 patient) and laparoscopic enterectomy in three patients. No other major intraoperative complications were encountered.

The postoperative evolution of these 6 cases was uneventful except one case of a pre-exiting parietal abscess and extended cellulitis who required 3 days of intensive care and prolonged local care to complete the healing.

No mesh infection was encountered.

Surgical site infection was encounter in two cases: one infected superficial hematoma, requiring local treatment in the POD 6 and one intraabdominal abscess after laparoscopic explant of the infected intraperitoneal mesh, requiring laparoscopic reintervention for lavage and drainage in POD 8.

The median postoperative hospital stay was 4 days (range 2-12 days), apparently not being influenced by the intraoperative complications. The median postoperative stay for the group with intraoperative incidents was 5.5 days (range 4-10 days) (Table 6).

If we compare the mean postoperative hospital stay of the group with acute or chronic sepsis versus the group without sepsis: 11 days (range 8-12 days) respectively 3 days (range 2-7 days), there is a statistically significant difference $(p<0,001)$. No postoperative 30 -day mortality occurred in the study group.

The median postoperative follow-up was 13.2 months (range 8 days - 3.6 years). Three recurrent incisional hernias are postoperatively encountered in these patients but, none of them were developed as a consequence of the laparoscopic exploration after IPOM. All these patients underwent laparoscopic (two patients) or open (one patient) sublay hernia repair.

\section{Discussions}

It is already demonstrated that postoperative adhesions (POA) can lead to high morbidity and mortality $(3,5)$. The 10-year readmission

Table 5. Risk factors for intraoperative incidents

\begin{tabular}{lcccc}
\hline & Incidents & No incidents & p value \\
\hline History of peritonitis & 4 & 5 & $0.056^{*}$ \\
\hline Open approach at last surgery & 4 & 3 & $0.018^{*}$ \\
\hline Digestive tract open at last surgery & 2 & 3 & 5 & $0.269^{*}$ \\
\hline Septic complication at last surgery & $3.5(3-11)$ & $3(1-14)$ & $0.305^{*}$ \\
\hdashline No. Abdominal surgery (median, range) & $3.5(3-9)$ & $1(0-13)$ & $0.067^{* *}$ \\
\hline No. Laparotomy (median, range) & & $0.005^{* *}$ \\
\hline
\end{tabular}

* Fisher's exact test; ${ }^{* *}$ Mann-Whitney test

Table 6. Median (range) postoperative hospital stay

\begin{tabular}{lccc}
\hline & with & without & p value $^{*}$ \\
\hline Intraoperative incidents & $5.5(4-10)$ & $3(2-12)$ & 0.062 \\
\hline Conversions & $5(4-6)$ & $3(2-12)$ & 0.267 \\
\hline Chronic or acute sepsis at admission & $11(8-12)$ & $3(2-7)$ & $<0.001$ \\
\hline
\end{tabular}

*Mann-Whitney test 
rate after any abdominal surgery probably or directly related to POA it could be as high as $30 \%(10,11)$. Any abdominal surgery indicated to these patients might have associated significant technical challenges (13).

The ventral hernia repair by using an intraperitoneal onlay mesh (IPOM) is reinforcing the abdominal wall by placing a prosthesis on the inner lining of the abdomen. The presence of the mesh into the peritoneum may increase the risk of POA. Halm (8) described an overall perioperative complication rate three times greater with subsequent abdominal surgery after IPOM (uncoated polypropylene) as compared with preperitoneal mesh.

Laparoscopic incisional and ventral hernia repair is an intraperitoneal technique, and the prosthetic biomaterial is placed intraabdominally lining the intact peritoneum and anchored to the anterior abdominal wall with a combination of mechanical fixation devices and transabdominal sutures (9).

Laparoscopic approach has become popular after Pierce (14) published a pooled data analysis of a selected group of incisional hernia repairs that confirmed fewer wound complications (3.8 vs. $16.8 \%$ ), fewer total complications (22.7 vs. $41.7 \%$ ), and fewer hernia recurrences (4.3 vs. $12.1 \%$ ) with laparoscopic technique compared to open procedure.

As all meshes produce adhesions when are intraperitoneally placed, it is an increasing concern regarding mesh-related adhesions whenever there is a need to re-explore the abdomen, by laparoscopy or an open approach. Moreover, the evaluation of the adhesions formed either after open or laparoscopic hernia mesh repair is limited and their presence is not associated with chronic pain (15).

Adhesions result from the fibrin exudates that follow any kind of trauma. These exudates form temporary adhesions until the fibrinolytic system absorbs the fibrin. Absorption is delayed in the presence ischemia, inflammation or foreign bodies (e.g. meshes). In these situations, they mature into tissue adhesions (16).

It is believed that adhesion prevention can be achieved by rapid restoration of a continuous mesothelial cell layer on top of a mesh (17). But,
Schreinemacher showed in his experimental study on rats (18) that adhesions can develop between structures that already are physiologically lined with a layer of mesothelial cells. There was no adhesion free mesh and the conclusion of the study was that commercially available synthetic meshes with different coatings performed equally well in terms of intraperitoneal adhesion prevention.

Although animal models have shown potential benefits, extrapolation to humans cannot be assumed and it may take many years before a solution, if any, will be found.

In our study, we didn't try to compare between different types of mesh, because of the limited number of cases and the continuously evolving mesh technology. However, we have encountered adherences even after biological mesh placement. Similar results revealed from Jenkins' study (12), mentioning adherences to the 8 biological meshes in over $60 \%$ of the surface and the mean adhesion tenacity of $2.9 \pm 0.4$.

Our study demonstrates that laparoscopic approach after previous IPOM is feasible.

The indication for laparoscopic surgery was various, related to the IPOM ventral hernia repair technique in 21 patients $(76 \%)$ and indicated for other pathologies in other 8 patients $(24 \%)$. Morbid obesity was the most encountered indication for surgery in this second group, and all the four patients underwent laparoscopic gastric sleeve as a metabolic procedure. Recurrent gastro esophageal reflux disease (GERD) after failed laparoscopic Nissen and diaphragmatic crus mesh reinforcement and IPOM ventral hernia repair was another indication for laparoscopy in our series. A laparoscopic Roux-en-Y gastric resection was performed as an efficient antireflux procedure. The list is completed with a laparoscopic procedure for colonic cancer, an adnexectomy and a nephrectomy.

All the respective videos of the laparoscopic procedures were recorded and stored in high quality digital files and there were entirely reviewed. The information consisted into the video files was extremely useful for this study. A well-organized video storage, respecting the 
rules of the personal data management is highly recommended for any surgical department performing endoscopic surgery.

The median time from the first attempt to introduce the optic trocar to the insertion of the first working trocar was $2 \mathrm{~min}$. There was no inadvertent opening of the digestive lumen at the insertion of the trocars.

Hasson technique for access to the peritoneum is known as the safest in a scared abdomen. However, in our experience there was no inadvertent opening of the digestive lumen at the insertion of the trocars.

Adherences to the mesh (POA) were present in the vast majority of the cases. No adherences to IPOM were identified only in one case in which an absorbable barrier coated mesh, fixed with metallic tackers was used and there were no other associated risk factors for adhesion. Three uneventful laparoscopic surgeries are encountered in the surgical history of this very patient.

Our study demonstrates that it is expected that, in IPOM procedure, over $60 \%$ of the surface of the mesh is covered by omentum, and in $40 \%$ of the cases, a hollow viscus it is also involved. In our experience in 2 cases the mesh was penetrating in the digestive lumen. Jenkins (12) has find in $76.8 \%$ of cases small bowel or colon adherent to the IPOM.

The surgical technique implies sharp dissection of the POA but we might be prepared to change the dissection plan, to continue between the mesh and the abdominal wall if needed (4 cases in our statistics).

We have to expect at half an hour of dissection to IPOM.

Laparoscopic approach after IPOM comes with a price, too: intraoperative incidents (20.6\%) and conversions (13.7\%). The conversion to open surgery is to be decided whenever the minimal-invasive surgery may affect the safety or the outcomes of the patient. Conversion to robotic surgery is to be limited to the availability of the DaVinci System and the procedure's costs. In our study, the advantages of the 3D perception and the accuracy of the dissection has supported the minim-invasive completion of a difficult dissection near-by a dilated urinary neobladder.

Inadvertent opening of the digestive lumen in our statistic compares with the $20.3 \%$ reported by Gray (19) for elective incisional hernia repair after previous mesh repair (open or laparoscopic, sublay mesh or IPOM), but it is twice the incidence reported by Itanifor laparoscopic ventral hernia repair (9\%) (20). This difference might be explained by the presence of multiple adhesions associated direct with the prosthesis in IPOM procedures.

As expected, the conversion rate is also higher than in the case of primary laparoscopic ventral hernia repair (1-14\%) (21).

As the IPOM is not the only or the most important risk factor for POA it is difficult to assess preoperatively which patients are at higher risk for complications. In our study, the risk to have complications during the $\mathrm{POA}$ dissection (mostly the opening of the digestive tract) trend to be significantly associated with: the open approach at last surgery and the number of former laparotomies. The septic complication at the last surgery and history of peritonitis had no influence on intraoperative complications in our series (Table 5).

The risk factors for POA which are associated with conversion are: septic complication at last surgery and the number of former laparotomies (Table 4).

In our experience intraoperative incidents and conversion didn't prolong significant the hospital stay but chronic or acute sepsis at admission had a significant impact on longer hospital stay $(\mathrm{p}<0.001)$ (Table 6).

The main limitations of our study are its retrospective design and the small numbers of cases that not permit to make definitive conclusions.

Continuing this study as a multicenter trial will facilitate a more critical evaluation of difficulties of adhesiolysis to previous IPOM, and to calculate odds ratio of risk factors.

\section{Conclusions}

Our study demonstrates that laparoscopic approach after previous IPOM is feasible. Adherences to the mesh are expected in the 
majority of the cases (96.5\%) but the tenacity may differ. History of peritonitis, a large number of open abdominal procedures and septic complication at last surgery correlate with the difficulty of laparoscopic adhesiolysis.

Chronic or acute sepsis at admission correlate with longer hospital stay.

This study has tobe continued as a multicenter trial.

\section{Conflict of Interest}

The authors declare no conflicts of interests.

\section{Author's Contributions}

All authors contributed equally to the manuscript.

\section{References}

1. Ouaïssi M, Gaujoux S, Veyrie N, Denève $E$, Brigand $C$, Castel $B$, et al. Post-operative adhesions after digestive surgery: Their incidence and prevention: Review of the literature. Journal of Visceral Surgery. 2012;149(2):e104-e14.

2. Tabibian N, Swehli E, Boyd A, Umbreen A, Tabibian JH. Abdominal adhesions: A practical review of an often overlooked entity. Ann Med Surg (Lond). 2017;15:9-13.

3. Van Der Krabben AA, Dijkstra FR, Nieuwenhuijzen M, Reijnen MM, Schaapveld M, Van Goor H. Morbidity and mortality of inadvertent enterotomy during adhesiotomy. Br J Surg. 2000; 87(4):467-71.

4. Burger JW, Luijendijk RW, Hop WC, Halm JA, Verdaasdonk EG, Jeekel J. Long-term follow-up of a randomized controlled trial of suture versus mesh repair of incisional hernia. Ann Surg. 2004;240(4):578-83; discussion 83-5.

5. Wullstein C, Gross E. Laparoscopic compared with conventional treatment of acute adhesive small bowel obstruction. $\mathrm{Br} \mathrm{J}$ Surg. 2003;90(9):1147-51.

6. Alpay Z, Saed GM, Diamond MP, editors. Postoperative adhesions: from formation to prevention. Seminars in reproductive Medicine; Thieme Medical Publishers; 2008.

7. Fortin CN, Saed GM, Diamond MP. Predisposing factors to postoperative adhesion development. Human Reproduction Update. 2015;21(4):536-51.
8. Halm JA, de Wall LL, Steyerberg EW, Jeekel J, Lange JF. Intraperitoneal polypropylene mesh hernia repair complicates subsequent abdominal surgery. World J Surg. 2007;31(2):423-9; discussion 30 .

9. LeBlanc KA, Booth WV. Laparoscopic repair of incisional abdominal hernias using expanded polytetrafluoroethylene: preliminary findings. Surg Laparosc Endosc. 1993;3(1):39-41.

10. Ellis H, Moran BJ, Thompson JN, Parker MC, Wilson MS, Menzies $\mathrm{D}$, et al. Adhesion-related hospital readmissions after abdominal and pelvic surgery: a retrospective cohort study. Lancet. 1999;353(9163):1476-80.

11. Parker MC, Ellis H, Moran BJ, Thompson JN, Wilson MS, Menzies D, et al. Postoperative adhesions: ten-year follow-up of 12,584 patients undergoing lower abdominal surgery. Dis Colon Rectum. 2001;44(6):822-29; discussion 9-30.

12. Jenkins ED, Yom V, Melman L, Brunt LM, Eagon JC, Frisella MM, et al. Prospective evaluation of adhesion characteristics to intraperitoneal mesh and adhesiolysis-related complications during laparoscopic re-exploration after prior ventral hernia repair. Surg Endosc. 2010;24(12):3002-7.

13. ten Broek RP, Issa Y, van Santbrink EJ, Bouvy ND, Kruitwagen RF, Jeekel $\mathrm{J}$, et al. Burden of adhesions in abdominal and pelvic surgery: systematic review and met-analysis. BMJ (Clinical research ed). 2013;347:f5588.

14. Pierce RA, Spitler JA, Frisella MM, Matthews BD, Brunt LM. Pooled data analysis of laparoscopic vs. open ventral hernia repair: 14 years of patient data accrual. Surg Endosc. 2007;21(3):378-86.

15. Langbach 0, Holmedal SH, Grandal OJ, \#xf8, kke 0. Adhesions to Mesh after Ventral Hernia Mesh Repair Are Detected by MRI but Are Not a Cause of Long Term Chronic Abdominal Pain \%J Gastroenterology Research and Practice. 2016;2016:7.

16. Brown CN, Finch JG. Which mesh for hernia repair? Annals of the Royal College of Surgeons of England. 2010;92(4):272-8.

17. Bellón JM, García-Honduvilla N, López R, Corrales C, Jurado F, Buján J. In vitro mesothelialization of prosthetic materials designed for the repair of abdominal wall defects. Journal of Materials Science: Materials in Medicine. 2003;14(4):359-64.

18. Schreinemacher MH, van Barneveld KW, Dikmans RE, Gijpels MJ, Greve JW, Bouvy ND. Coated meshes for hernia repair provide comparable intraperitoneal adhesion prevention. Surg Endosc. 2013;27(11):4202-9.

19. Gray SH, Vick CC, Graham LA, Finan KR, Neumayer LA, Hawn MT. Risk of complications from enterotomy or unplanned bowel resection during elective hernia repair. Arch Surg. 2008; 143(6): 582-6.

20. Itani KM, Neumayer L, Reda D, Kim L, Anthony T. Repair of ventral incisional hernia: the design of a randomized trial to compare open and laparoscopic surgical techniques. Am J Surg. 2004;188(6A Suppl):22S-9S

21. Earle DR, S Saber,A Haggerty,S Bradley III, JF Fanelli R Price R Richardson WS Stefanidis D. 2016. https://www.sages.org/ publications/guidelines/guidelines-for-laparoscopic-ventral-herniarepair/ 